\title{
Maintaining Christian virtues and ethos in Christian universities in Ghana: The reality, challenges and the way forward
}

\begin{tabular}{|c|c|}
\hline \multicolumn{2}{|c|}{$\begin{array}{l}\text { Authors: } \\
\text { Peter White } 1 \\
\text { Samuel K. Afrane }\end{array}$} \\
\hline \multicolumn{2}{|c|}{$\begin{array}{l}{ }^{1} \text { Department of Science of } \\
\text { Religion and Missiology, } \\
\text { Faculty of Theology, } \\
\text { University of Pretoria, } \\
\text { South Africa }\end{array}$} \\
\hline \multicolumn{2}{|c|}{$\begin{array}{l}{ }^{2} \text { Office of the President, } \\
\text { Christian Service University } \\
\text { College, Ghana }\end{array}$} \\
\hline \multicolumn{2}{|c|}{$\begin{array}{l}\text { Research Project } \\
\text { Registration: } \\
\text { Project Leader: N. Niemandt } \\
\text { Project Number: } 04317734\end{array}$} \\
\hline \multicolumn{2}{|c|}{$\begin{array}{l}\text { Description: } \\
\text { Dr White is participating in } \\
\text { the research project, } \\
\text { 'Ecodomy', directed by Prof. } \\
\text { Dr Nelus Niemandt, } \\
\text { Department of Science of } \\
\text { Religion and Missiology, } \\
\text { Faculty of Theology, } \\
\text { University of Pretoria, } \\
\text { South-Africa. }\end{array}$} \\
\hline \multicolumn{2}{|c|}{$\begin{array}{l}\text { Corresponding author: } \\
\text { Peter White, } \\
\text { pastor_white@hotmail.com }\end{array}$} \\
\hline $\begin{array}{l}\text { Dates: } \\
\text { Received: } 28 \text { I } \\
\text { Accepted: } 14 \\
\text { Published: } 19\end{array}$ & $\begin{array}{l}\text { Jov. } 2016 \\
\text { Apr. } 2017 \\
\text { June } 2017\end{array}$ \\
\hline \multicolumn{2}{|c|}{$\begin{array}{l}\text { How to cite this article: } \\
\text { White, P. \& Afrane, S.K., } \\
\text { 2017, 'Maintaining Christian } \\
\text { virtues and ethos in Christian } \\
\text { universities in Ghana: The } \\
\text { reality, challenges and the } \\
\text { way forward', HTS Teologiese } \\
\text { Studies/Theological Studies } \\
\text { 73(3), 4442. https://doi. } \\
\text { org/10.4102/hts.v73i3.4442 }\end{array}$} \\
\hline \multicolumn{2}{|l|}{ Read online: } \\
\hline 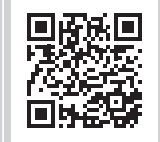 & $\begin{array}{l}\text { Scan this QR } \\
\text { code with your } \\
\text { smart phone or } \\
\text { mobile device } \\
\text { to read online. }\end{array}$ \\
\hline
\end{tabular}

Christian universities are established to integrate Christian faith, principles and virtues into their academic programmes with the expectation that through this holistic Christocentric education, students will be well-prepared to serve and to contribute positively to transform society. Although this approach to education is good, it however does not come without the challenge of how to maintain these Christian virtues in light of increasing secularisation and permissiveness in contemporary society. This article examines the realities and challenges of maintaining Christian virtues and ethos in Christian universities in Ghana and recommends some helpful solutions. The study employed eclectic methodology in data gathering and analyses. The research revealed that for a university to be called a Christian university, it must have at its core the vision for Christcentredness, mission mindedness and discipleship focus. This must also be reflected in the attitude of both students and staff in the way they relate to and manage God's resources.

\section{Introduction}

Universities are established purposely for training and educating a high calibre of professionals for national development, but it is gradually becoming clear that academic certification alone is not enough in this competitive world. Apart from academic qualifications and relevant skills, the corporate world is searching for people with strong Christian virtues such as moral integrity, honesty and hard work. These virtues can only be acquired when faith is integrated in the academic lives of students.

Integrating Christian values in the academic lives of students is an area of less concern for many public universities. Christian universities are, therefore, established to fill this faith gap by integrating Christian principles and virtues into the academic life of all enrolled students. Their ultimate purpose is that through this holistic Christocentric education, students will be fully prepared to offer honest services and contribute positively to transform society. Although this approach to education is good, it however does not come without the challenge of how to maintain these Christian virtues and ethos in many of these universities, especially in the light of secularisation and modernity in contemporary society as well as issues related to policies and requirements for institutional accreditation. This article seeks to present the realities and challenges of maintaining Christian virtues and ethos in some selected Christian universities in Ghana, and to recommend some helpful practical ways in addressing the challenges.

\section{Methodology}

The study employed a mixed method for data gathering. Primary data were collected through questionnaires administered to students, lecturers and senior administrators of the universities under study. Seventy-two questionnaires were administered in three private Christian university colleges in Ghana [Christian Service University College (CSUC), Pentecost University College (PUC) and Methodist University College (MUC)]. In each university, a total number of 24 questionnaires were administered. Fifteen went to students, five to lecturers and four to administrative staff. However, 70 questionnaires were retrieved and analysed using Statistical Package for Social Sciences (SPSS) and the results were presented in a descriptive cross tabulated statistics format under various subheadings. The purpose of this article is not to do a comparative study, but to make a case from the data collected from the three University Colleges. The University Colleges were presented in the data output according to their church tradition:

- CSUC - Evangelical.

- PUC - Pentecostal.

- MUC-Orthodox.

Copyright: (C) 2017. The Authors. Licensee: AOSIS. This work is licensed under the Creative Commons Attribution License. 
Secondary data were collected through the websites, students' handbooks and policy documents of the University Colleges used for the study.

\section{Limitation of the study}

Looking at the fact that the filed data is a kind of selfassessment from the various universities, there is the possibility that the respondents may not be objective. The answers provided may be subjective.

Furthermore, because there is no common ground or basis for the various universities' definition or understanding of issues such as discipline, modesty, opposite sex relationships and application of Biblical principles in various matters, the differences that were derived in the cross tabulated data output may be perceptional differences.

\section{Brief history of the Christian universities under study}

Christian Service University College was established in 1974 as a result of a merger between a group of Ghanaian Christians and expatriate missionaries with a vision to establish an interdenominational, Evangelical institution of a high academic standard, which would train men and women for all types of Christian Ministry. The Worldwide Evangelization for Christ (WEC), which was one of the missionary groups of the expatriate missionaries, had by then acquired property in Kumasi on which they had built four dwelling houses and a radio studio with plans to construct a large building to serve as the beginning of a training college. In October 1974, the first residential classes started with four students. The college, which started as a place for only theological studies, was given accreditation in 2006 by the National Accreditation Board (NAB) to run other programmes. The University College is currently made up of School of Graduate Studies, School of Business, Faculty of Humanities and Faculty of Health and applied Sciences (CSUC 2016a). This constitutes students of the regular stream, evening school and weekend school.

The vision of CSUC is to be a first-class Evangelical Christian University that promotes knowledge about Christ through the training of men and women with moral uprightness, academic excellence and passion to serve and transform society (CSUC 2016b).

Unlike CSUC which was not founded by a particular denomination but is believed to be Evangelical, the PUC was founded by the Church of Pentecost. The University College traces its history to 1954 when the Church of Pentecost started the World Mission Bible College (WMBC). In February 1972, WMBC which had not been active for a long time was restarted as the Pentecost Bible Centre (PBC) at the McKeown Temple in Kumasi with an initial enrolment of five students for 2 years. The centre was later moved from Kumasi to Madina in Accra in 1984. In March 2003, the Pentecost Bible College was upgraded to a University College, and was granted Institutional Accreditation by the NAB in November 2004. The first batch of students was enrolled in February, 2005 (PUC 2010).

The PUC is currently made up of three faculties (Faculty of Theology and Mission, Faculty of Business Administration and Faculty of Engineering, Science and Computing) as well as a School of Graduate Studies.

Their vision is to empower students to serve their own generation and posterity with integrity and the fear of God. Their mission is to be on the cutting-edge of the dissemination of knowledge, quality education, research and training for the purpose of producing an excellent human resource base to meet the demands of Ghana's development (PUC 2016b).

Coming to the MUC, history tells us that the Wesleyan Mission Society arrived in Ghana in 1835. Since then, the Methodist Church has been involved in the provision and development of high quality education at basic senior secondary and teacher training levels. The church decided at its 36th Annual Conference held in Cape Coast (1997) to establish a MUC. After due preparations and processes, the Methodist University College Ghana (MUCG) was granted accreditation by the NAB in August 2000. The first batch of students reported for lectures in November 2000 (MUC 2016b). The University College is currently made up of five faculties (Applied Sciences, Arts and General Studies, Business Administration, Informatics \& Mathematical Sciences and Social Studies) with campuses in Dansoman, Abetifi, Tema and Wenchi in the Brong-Ahafo Region (MUC 2016a).

Their vision and mission are:

To impart knowledge and skills in disciplines relevant to national development within the context of general global development, and at the same time an all-round development of the student mentally, physically and spiritually on the basis of Christian principles. (MUC 2016c)

Looking at the vision and mission statements of the university colleges being discussed, it is a fact that their purpose is to integrate Christian principles in the lives of the enrolled students. It should be noted that the purpose of this article is not to deliberate on the vision and mission statements of the universities under study but to focus their agenda to integrate Christian principles into the academic lives of their students, the various mechanisms to put in place to achieve this purpose as well as some of the challenges of maintaining virtues in Christian universities in Ghana.

\section{The overview of being a Christian university}

It is not enough to claim to be a Christian university. A university being founded by a church does not mean that it is a Christian university. A university having the word 'Christian' or the name 'Christ' as part of their name or vision and mission statement does not make it a Christian university. 
What we should not forget is that there is evidence of universities that started with clear Christian philosophies of education and commitment to sound doctrine but have over time abandoned their commitment to the basic tenets of the faith.

What defines a university as a Christian university is that, it must be Christ-centred, mission minded and discipleship focused. These three attributes are in line with the great commission and are the basic principles that will transform the lives of the enrolled students. It also helps them to see their academic training as an opportunity to develop their capacities to become agents of transformation and ambassadors of Christ. It gives students the confidence and assurance that their future is secured.

To be Christ-centred means to see Jesus Christ as the centre of every activity that goes on in the university. This includes the academic, administrative and spiritual lives of the staff and students of the university (English \& Bowman 2001:37-52).This worldview is a catalyst that enhances people's personal relationship with Christ and also helps them to articulate their faith within real life experiences in the changing dynamics of today's world (Chiroma 2012:246; Rock 2006:54).

To be mission minded means seeing the university campus as a mission field whereby every student is seen as a candidate for heaven. 'A candidate for heaven' in this context implies that:

- The person has already accepted Jesus Christ as his or her personal saviour and Lord.

- The person has no relationship with Jesus Christ but for the fact that he or she becomes part of the university, we have the responsibility to ensure that by the time they are leaving the university for the job market they would have been introduced to Christ.

The word 'mission' is, first and foremost, about God and his redemptive initiative on behalf of creation (Tennent 2010:59). According to Newbigin, mission is the proclamation of the kingdom of the Father, sharing the life of the Son, and bearing the witness of the Holy Spirit (1978:31). All Christians and Christian institutions are, therefore, called to be vibrant messengers of the gospel of Jesus Christ, which is the good news of salvation (World Council of Churches [WCC] 2013:53). This, therefore, calls for spiritual discernment to design mission focused strategies and programmes for the university by joining in with the Holy Spirit to know what the Father (God) is doing in one's context (Kim 2009:256; Lonsdale 2005:240; WCC 2013:52, 56-57).

Being discipleship focused as a Christian university means creating and enabling an environment that will help students and staff to have a continuous relationship with Jesus Christ, relying on the Holy Spirit to have a deeper knowledge about Christ and being transformed into the image of Jesus Christ (Bosch 1991:56; Kretzschmar 2006:344-345; Walls \& Ross 2008:24-35; Wright 2006:391).
Another component of what defines a university as a Christian university is when the staff of the university see their appointment more as a call to serve than a career. When work is seen as a call, it changes the mind-set of the workers and makes them see Christ as their main employer. They also see their work as an opportunity to serve in God's vineyard. This also helps to create an atmosphere of love and harmony among the various classes of people.

The final characteristic of what defines an institution as a Christian university is the sense of stewardship among students and staff. The cornerstone of stewardship is the full acknowledgement and consistent practice of allowing God to direct what he wants to be done with what he has entrusted us to manage. Stewardship defines our practical obedience in the administration of everything under our control, and everything entrusted to us.

The sense of stewardship is what makes both staff and students to see themselves as being first of all accountable to God. It also helps people to diligently manage what has been entrusted into their care (i.e. students, money, materials and assets). Stewardship encompasses the way we live our lives and manage our time and the resources of God. It creates the awareness that everyone shall give account of himself or herself to God and be rewarded (Rm 14:12, Rv 22:12).

\section{The realities in maintaining Christian virtues and ethos in Christian universities in Ghana}

Our view at this point is to discuss what is happening and has been put in place by Christian universities in Ghana in their efforts to maintain Christian virtues and ethos on their campuses. We will discuss how Christian virtues and principles have been integrated into the academic programmes of the universities, Chaplaincy programmes on campus and students' participation, modesty and the opposite sex relationships, as well as discipline on the campuses of the university colleges used for the study.

\section{Integrating Christian principles and virtues into academic programmes}

Virtue is often referred to as moral excellence, goodness and conformity of life and conduct with the principles of morality. According to Christian teaching, theological virtue does not originate from natural man. It is imparted by God through Christ and then practised by the believer (Encyclopædia Britannica Online 2016). Christian virtue can be described as having a godly excellence, a godly goodness or a godly righteousness. It is the application of a conscious will to do what is right from God's revealed Word and from personal responsibility. It encompasses integrity, honesty, modesty and purity. Virtue is not only there to serve as a guide for our daily lives or decisions but also to help us give the best of ourselves. 
In order to address the challenges of the current generation and beyond, there is the need for both students and staff to have a holistic Christocentric approach to teaching and learning. This is made possible when Christian principles and virtues are integrated into academic programmes or the curriculum of the university.

The quest to give students the best training and to ensure that Christian virtues are upheld and integrated into the academic life of students in the CSUC led to the introduction of the Faith and Practice Programme (FAPP). FAPP is a Christ-centred mentorship programme which was initially piloted and coordinated in the March-April 2013 and March-April 2014 academic years, with students from the Theology and Communication Departments. It was later extended to the various departments in the 2014 and 2015 academic years. At this implementation stage, the entire student body was divided into 94 Mentor Groups according to the various sections of students (Regular, Evening and Weekend). Group meetings were, therefore, scheduled in the second week of every month to discuss the topic for the month. The ultimate objective of FAPP is that, upon successful completion of the programme, students will be equipped to become leaders with scholarly depth, reflective faith, moral uprightness, as well as equipped with the skills to serve and educate church and society (White, Okai \& Asabea-Aboagye 2015:60).

A similar programme was also introduced at the PUC. Although the programme was initiated by Prof. Stephen Adei, the Rector, Rev. Dr. Peter Ohene Kyei in 2012 adopted it as a mandatory part of all undergraduate degrees of the University College. The aim of the programme is to contribute to the personal, relational, intellectual, professional and spiritual development of their students. Students in levels 100 and 400 of regular school are mentored by Faculty and Staff, while level 200 and 300 students are mentored by some selected students in levels 300 and 400, respectively. The meetings are held for level 100 and 300 students on Tuesdays between 1.15 pm and $2.15 \mathrm{pm}$ and level 200 and 400 students organise theirs on Thursdays, between $1.15 \mathrm{pm}$ and $2.15 \mathrm{pm}$. The Evening and Weekend students are mentored by the Church of Pentecost Ministerial students on Fridays, from $6.00 \mathrm{pm}-6.30 \mathrm{pm}$. There are instances where mentors and mentees meet at a more convenient time for both parties (PUC 2016a).

In spite of the fact that the university colleges being discussed have introduced programmes that will help integrate Christian principles and virtues into the lives of their students, this is not enough. One must also think of the lifestyle and spiritual maturity of the facilitators of these programmes as well as that of the staff of the institution. About $40.0 \%$ of the respondents indicate that lecturers in most cases do integrate Biblical principles into their lectures, while $58.6 \%$ were of the view that lecturers do so in limited cases. A further study to ascertain how lecturers present themselves in their teaching or lecture halls, $50.0 \%$ and $47.1 \%$ of the respondents revealed that lecturers do present themselves as Christians to a high and limited extent, respectively (Tables 1 and 2). In Table 2, $62.5 \%$ of the respondents indicated that the Evangelical lecturers present themselves as Christians to a large extent, followed by the Pentecostals (50.0\%) and the Orthodox $(36.4 \%)$

\section{Chaplaincy programmes on campuses and participation of students and staff}

As the scripture says, 'Train up a child in the way he should go, and when he is old he will not depart from it' (Pr 22:6). It is, therefore, a great responsibility for us as leaders and staff of Christian universities to not only think of the academic lives of our students, but also their spiritual lives.

Our study also reveals that all the universities under study provide the office of a chaplain. The main objective for establishing the office of a university chaplain is to attend to the spiritual needs of both students and staff. According to Coffey, spirituality reflects 'a broader dimension of day-today activity' (2002:5). It shapes our actions and is directly related to our values and to our ethical behaviour (Chittenden 2003:16). It is also reflected in our sense of who we are and where we come from, our beliefs about why we are here - the meaning and purpose we see in our lives - and our connectedness to each other and to the world around us (Lindholm et al. 2011:4).

Our field data indicated that the University Colleges used for study do organise regular weekly church services for the university community. However, $30.0 \%$ of the respondents indicated that student attendance is always between $61.0 \%$ and $80.0 \%$ of the entire student population. The same applies to lecturers and other staff. A cross tabulation of the various church traditions as far as participation in campus church services are concerned shows that the statistics of the evangelicals $(37.5 \%$ - students, $20.8 \%$ - lecturers and $29.2 \%$ - other staff) is somehow encouraging compared to the other church traditions (Tables 3-5).

TABLE 1: Lecturers' integration of Biblical principles and examples in their lectures.

\begin{tabular}{lcccc}
\hline Church tradition & \multicolumn{2}{c}{$\begin{array}{c}\text { Lecturers' integration of Biblical principles and } \\
\text { examples in their lectures }\end{array}$} & $\begin{array}{c}\text { Total } \\
\mathbf{( \% )}\end{array}$ \\
\cline { 2 - 4 } & $\begin{array}{c}\text { In most cases } \\
\mathbf{( \% )}\end{array}$ & $\begin{array}{c}\text { In limited cases } \\
\mathbf{( \% )}\end{array}$ & $\begin{array}{c}\text { Not at all } \\
\mathbf{( \% )}\end{array}$ & \\
\hline Evangelical & 41.7 & 58.3 & - & 100.0 \\
Pentecostal & 45.8 & 54.2 & - & 100.0 \\
Orthodox & 31.8 & 63.6 & 4.5 & 100.0 \\
\hline Total (\%) & $\mathbf{4 0 . 0}$ & $\mathbf{5 8 . 6}$ & $\mathbf{1 . 4}$ & $\mathbf{1 0 0 . 0}$ \\
\hline
\end{tabular}

TABLE 2: How lecturers present themselves as Christian in their teaching.

\begin{tabular}{lcccc}
\hline Church tradition & \multicolumn{2}{c}{ How lecturers present themselves as Christian in } & \multirow{2}{*}{$\begin{array}{c}\text { Total } \\
\text { their teaching }\end{array}$} \\
\cline { 2 - 4 } & $\begin{array}{c}\text { To a high extend } \\
(\mathbf{\%})\end{array}$ & $\begin{array}{c}\text { Limited extend } \\
(\%)\end{array}$ & $\begin{array}{c}\text { Not at all } \\
(\%)\end{array}$ & \\
\hline Evangelical & 62.5 & 37.5 & - & 100.0 \\
Pentecostal & 50.0 & 41.7 & 8.3 & 100.0 \\
Orthodox & 36.4 & 63.6 & - & 100.0 \\
\hline Total (\%) & $\mathbf{5 0 . 0}$ & $\mathbf{4 7 . 1}$ & $\mathbf{2 . 9}$ & $\mathbf{1 0 0 . 0}$ \\
\hline
\end{tabular}




\section{Modesty on campuses}

Modesty is a respectable manner of adorning one's body and carrying oneself, born out of a freedom from a worldly definition of beauty and worth, and motivated by a hatred of sin and a desire to draw attention to God (Gilkerson 2013). Although we fully agree that modesty is contextual, African culture frowns on indecent dressing. The key to understanding what constitutes modesty in dress is to examine the attitudes and intents of the heart. Modesty aims at being decent in all things, at all times and at all places. The apostle Paul admonishes believers (men and women) to dress modestly, with decency and propriety (1 Tm 2:9).

Many young ladies and men in contemporary times are blindly following an influx of so called 'modern fashion'. This, therefore, throws a challenge to Christian universities to show them the proper way to dress for various functions. Let's not forget that our focus as Christian universities is not to educate people, but rather our kind of education should be holistic and transformational. Until our students are transformed by our education, it is impossible to transform society.

Our study has revealed that all the universities being used for this research have prescribed a form of dress they deemed to be appropriate for their students in their students' handbooks. However, these dress codes are not seriously enforced by the authorities of the institutions. Tables 6-10 are a representation of how respondents assessed the dressing of students and staff of the universities used for the study. The tables indicate that the dress code on the selected university campuses is progressively good at various angles. However, the Pentecostals are doing better than the other two faith traditions. About $41.7 \%$ of the respondents are of the view that the dress code of the staff is very good, and $45.8 \%$ and $25.0 \%$ of the respondents also

TABLE 3: Average attendance of students.

\begin{tabular}{lccccc}
\hline $\begin{array}{l}\text { Church } \\
\text { tradition }\end{array}$ & \multicolumn{5}{c}{ Average attendance of students } \\
\cline { 2 - 6 } & $\mathbf{1 - 2 0 ( \% )}$ & $\mathbf{2 1 - 4 0 ~ ( \% )}$ & $\mathbf{4 1 - 6 0 ~ ( \% )}$ & $\mathbf{6 1 - 8 0 ~ ( \% )}$ & $\mathbf{8 1 - 1 0 0 ~ ( \% ) ~}$ \\
\hline Evangelical & 4.2 & 20.8 & 20.8 & 37.5 & 16.7 \\
Pentecostal & 12.5 & - & 4.2 & 20.8 & 62.5 \\
Orthodox & 13.6 & 22.7 & 27.3 & 31.8 & 4.5 \\
\hline Total (\%) & $\mathbf{1 0 . 0}$ & $\mathbf{1 4 . 3}$ & $\mathbf{1 7 . 1}$ & $\mathbf{3 0 . 0}$ & $\mathbf{2 8 . 6}$ \\
\hline
\end{tabular}

TABLE 4: Average attendance of lecturers.

\begin{tabular}{lccccc}
\hline $\begin{array}{l}\text { Church } \\
\text { tradition }\end{array}$ & \multicolumn{5}{c}{ Average attendance of lecturers } \\
\cline { 2 - 6 } & $\mathbf{1 - 2 0 ~ ( \% )}$ & $\mathbf{2 1 - 4 0 ~ ( \% )}$ & $\mathbf{4 1 - 6 0 ~ ( \% )}$ & $\mathbf{6 1 - 8 0 ~ ( \% ) ~}$ & $\mathbf{8 1 - 1 0 0 ~ ( \% ) ~}$ \\
\hline Evangelical & 37.5 & 4.2 & 12.5 & 20.8 & 25.0 \\
Pentecostal & 41.7 & 16.7 & 20.8 & 4.2 & 16.7 \\
Orthodox & 22.7 & 18.2 & 18.2 & 22.7 & 18.2 \\
\hline Total (\%) & $\mathbf{3 4 . 3}$ & $\mathbf{1 2 . 9}$ & $\mathbf{1 7 . 1}$ & $\mathbf{1 5 . 7}$ & $\mathbf{2 0 . 0}$ \\
\hline
\end{tabular}

TABLE 5: Average attendance of other staff.

\begin{tabular}{lccccc}
\hline $\begin{array}{l}\text { Church } \\
\text { tradition }\end{array}$ & \multicolumn{5}{c}{ Average attendance of other staff } \\
\cline { 2 - 6 } & $\mathbf{1 - 2 0 ( \% )}$ & $\mathbf{2 1 - 4 0 ~ ( \% )}$ & $\mathbf{4 1 - 6 0 ~ ( \% )}$ & $\mathbf{6 1 - 8 0 ~ ( \% ) ~}$ & $\mathbf{8 1 - 1 0 0 ~ ( \% ) ~}$ \\
\hline Evangelical & 29.2 & 16.7 & 20.8 & 29.2 & 4.2 \\
Pentecostal & 45.8 & 25.0 & 12.5 & 8.3 & 8.3 \\
Orthodox & 22.7 & 22.7 & 22.7 & 18.2 & 13.6 \\
\hline Total (\%) & $\mathbf{3 2 . 9}$ & $\mathbf{2 1 . 4}$ & $\mathbf{1 8 . 6}$ & $\mathbf{1 8 . 6}$ & $\mathbf{8 . 6}$ \\
\hline
\end{tabular}

share a similar view on the dress code of both males and females (Tables 9-10).

\section{Opposite sex relationship, discipline and enforcement of Christian principles on campus}

As part of our objective to ascertain the realities going on at the various campuses, we found it necessary to also consider the issue of opposite sex relationships, discipline and how these issues are enforced on various campuses. Although reports regarding issues related to rape and sexual harassment in Christian universities in Ghana are minimal, the data from our study has emphasised this fact. About $84.3 \%$ of the respondents indicated that opposite sex relationships on various campuses are decent (Table 11).

It is the expectation of leaders of Christian universities that staff and student conduct be grounded in Biblical principles. Each member of the university is expected to uphold these

TABLE 6: Dress of students on campus.

\begin{tabular}{lccccc}
\hline $\begin{array}{l}\text { Church } \\
\text { tradition }\end{array}$ & \multicolumn{4}{c}{ Dress of students on campus } & Total (\%) \\
\cline { 2 - 5 } & $\begin{array}{c}\text { Very good } \\
(\mathbf{\%})\end{array}$ & $\begin{array}{c}\text { Good } \\
(\mathbf{\%})\end{array}$ & $\begin{array}{c}\text { Poor } \\
(\mathbf{\%})\end{array}$ & $\begin{array}{c}\text { Very poor } \\
(\mathbf{\%})\end{array}$ & \\
\hline Evangelical & - & 75 & 20.8 & 4.2 & 100.0 \\
Pentecostal & 16.7 & 62.5 & 16.7 & 4.2 & 100.0 \\
Orthodox & 18.2 & 63.6 & 18.2 & - & 100.0 \\
\hline Total (\%) & $\mathbf{1 1 . 4}$ & $\mathbf{6 7 . 1}$ & $\mathbf{1 8 . 6}$ & $\mathbf{2 . 9}$ & $\mathbf{1 0 0 . 0}$ \\
\hline
\end{tabular}

TABLE 7: Dress of teaching staff on campus.

\begin{tabular}{lccc}
\hline Church tradition & \multicolumn{2}{c}{ Dress of teaching staff on campus } & \multirow{2}{*}{ Total (\%) } \\
\cline { 2 - 3 } & Very good (\%) & Good (\%) & \\
\hline Evangelical & 58.3 & 41.7 & 100.0 \\
Pentecostal & 58.3 & 41.7 & 100.0 \\
Orthodox & 59.1 & 40.9 & 100.0 \\
\hline Total (\%) & $\mathbf{5 8 . 6}$ & $\mathbf{4 1 . 4}$ & $\mathbf{1 0 0 . 0}$ \\
\hline
\end{tabular}

TABLE 8: Assessment of the dress of non-staff on campus.

\begin{tabular}{lcccc}
\hline \multirow{2}{*}{ Church tradition } & \multicolumn{2}{c}{ Assessment of the dress of non-staff on campus } & \multirow{2}{*}{ Total (\%) } \\
\cline { 2 - 4 } & Very good (\%) & Good (\%) & Poor (\%) & \\
\hline Evangelical & 37.5 & 54.2 & 8.3 & 100.0 \\
Pentecostal & 41.7 & 37.5 & 20.8 & 100.0 \\
Orthodox & 36.4 & 63.6 & - & 100.0 \\
\hline Total (\%) & $\mathbf{3 8 . 6}$ & $\mathbf{5 1 . 4}$ & $\mathbf{1 0 . 0}$ & $\mathbf{1 0 0 . 0}$ \\
\hline
\end{tabular}

TABLE 9: Assessment of the dress of male's on campus.

\begin{tabular}{lccccc}
\hline $\begin{array}{l}\text { Church } \\
\text { tradition }\end{array}$ & \multicolumn{2}{c}{ Assessment of the dress of male's on campus } & \multirow{2}{*}{ Total (\%) } \\
\cline { 2 - 5 } & $\begin{array}{c}\text { Very good } \\
(\mathbf{\%})\end{array}$ & $\begin{array}{c}\text { Good } \\
\mathbf{( \% )}\end{array}$ & $\begin{array}{c}\text { Poor } \\
(\mathbf{\%})\end{array}$ & $\begin{array}{c}\text { Very poor } \\
(\mathbf{\%})\end{array}$ & \\
\hline Evangelical & 29.2 & 62.5 & 8.3 & - & 100.0 \\
Pentecostal & 45.8 & 37.5 & 12.5 & 4.2 & 100.0 \\
Orthodox & 45.5 & 50.0 & 4.5 & - & 100.0 \\
\hline Total (\%) & $\mathbf{4 0 . 0}$ & $\mathbf{5 0 . 0}$ & $\mathbf{8 . 6}$ & $\mathbf{1 . 4}$ & $\mathbf{1 0 0 . 0}$ \\
\hline
\end{tabular}

TABLE 10: Assessment of the dress of females on campus.

\begin{tabular}{llllll}
\hline $\begin{array}{l}\text { Church } \\
\text { tradition }\end{array}$ & \multicolumn{2}{c}{ Assessment of the dress of females on campus } & \multirow{2}{*}{ Total (\%) } \\
\cline { 2 - 5 } & $\begin{array}{c}\text { Very good } \\
(\mathbf{\%})\end{array}$ & $\begin{array}{c}\text { Good } \\
(\mathbf{\%})\end{array}$ & $\begin{array}{c}\text { Poor } \\
\mathbf{( \% )}\end{array}$ & $\begin{array}{c}\text { Very poor } \\
(\mathbf{\%})\end{array}$ & \\
\hline Evangelical & 20.8 & 41.7 & 29.2 & 8.3 & 100.0 \\
Pentecostal & 25.0 & 58.3 & 12.5 & 4.2 & 100.0 \\
Orthodox & 27.3 & 54.5 & 13.6 & 4.5 & 100.0 \\
\hline Total (\%) & $\mathbf{2 4 . 3}$ & $\mathbf{5 1 . 4}$ & $\mathbf{1 8 . 6}$ & $\mathbf{5 . 7}$ & $\mathbf{1 0 0 . 0}$ \\
\hline
\end{tabular}


TABLE 11: Relationships between the opposite sexes on campus.

\begin{tabular}{lcccc}
\hline \multirow{2}{*}{$\begin{array}{l}\text { Church } \\
\text { tradition }\end{array}$} & \multicolumn{2}{c}{ Relationships between the opposite sexes on campus } & Total (\%) \\
\cline { 2 - 4 } & Very decent (\%) & Decent (\%) & Unhealthy (\%) & \\
\hline Evangelical & 8.3 & 91.7 & - & 100.0 \\
Pentecostal & 4.2 & 83.3 & 12.5 & 100.0 \\
Orthodox & 9.1 & 77.3 & 13.6 & 100.0 \\
\hline Total (\%) & $\mathbf{7 . 1}$ & $\mathbf{8 4 . 3}$ & $\mathbf{8 . 6}$ & $\mathbf{1 0 0 . 0}$ \\
\hline
\end{tabular}

TABLE 12: Discipline on campus.

\begin{tabular}{lcccc}
\hline \multirow{2}{*}{$\begin{array}{l}\text { Church } \\
\text { tradition }\end{array}$} & \multicolumn{3}{c}{ Discipline on campus } & Total (\%) \\
\cline { 2 - 4 } & High (\%) & Average (\%) & Poor (\%) & \\
\hline Evangelical & 16.7 & 79.2 & 4.2 & 100.0 \\
Pentecostal & 33.3 & 62.5 & 4.2 & 100.0 \\
Orthodox & 27.3 & 59.1 & 13.6 & 100.0 \\
\hline Total (\%) & $\mathbf{2 5 . 7}$ & $\mathbf{6 7 . 1}$ & $\mathbf{7 . 1}$ & $\mathbf{1 0 0 . 0}$ \\
\hline
\end{tabular}

TABLE 13: Enforcement of Christian principles and examples on campus.

\begin{tabular}{lcccc}
\hline $\begin{array}{l}\text { Church } \\
\text { tradition }\end{array}$ & \multicolumn{2}{c}{ Enforcement of Christian principles and examples on campus } \\
\cline { 2 - 5 } & High (\%) & $\begin{array}{c}\text { Limited extend } \\
(\mathbf{\%})\end{array}$ & $\begin{array}{c}\text { Week } \\
\text { enforcement } \\
(\mathbf{\%})\end{array}$ & $\begin{array}{c}\text { Very } \\
\text { enforcement } \\
(\mathbf{\%})\end{array}$ \\
\hline Evangelical & 29.2 & 25.0 & 41.7 & 4.2 \\
Pentecostal & 45.8 & 50.0 & - & 4.2 \\
Orthodox & 45.5 & 31.8 & 18.2 & 4.5 \\
\hline Total (\%) & $\mathbf{4 0 . 0}$ & $\mathbf{3 5 . 7}$ & $\mathbf{2 0 . 0}$ & $\mathbf{4 . 3}$ \\
\hline
\end{tabular}

values through integrity, honesty, trust, fairness and respect toward peers and the community. However, as a community of Christian scholars, the university expects from its staff and students a higher standard of conduct. About $67.1 \%$ of the respondents were of the view that discipline on various campuses is average. An assessment of how Christian principles and examples on campus are enforced demonstrates that Christian principles are averagely enforced. About $40.0 \%$ of the respondents indicated it to be highly enforced while $35.7 \%$ were of the view that Christian principles are enforced to a limited extent (Tables 12 and Table 13). As far as discipline and enforcing Christian principles are concerned, the Pentecostals are doing well. About $33.3 \%$ and $45.8 \%$ of the respondents from the Pentecostals, respectively, indicated that both issues are being implemented at a high level. It is however interesting to note that the Orthodox are almost parallel to the Pentecostals on the enforcement of Biblical principles and examples on the campuses (Table 13).

\section{Challenges of maintaining virtues in Christian universities in Ghana}

Considering that Christians and Christian universities are part of the world and its changing dynamics, there is no way, we can say, we are immune to the effects of secularisation, modernity, technological advancement and issues related to human rights. The issues raised are some of the major issues that are affecting many Christian universities in Ghana in their effort to maintain their Christian identity. The views shared here were unearthed through personal observation and experience as a lecturer and senior administrator in one of the universities used for the study. These views were shared in the light of other relevant scholarly literature.

\section{Secularisation and modernity}

Secularisation is the theory in sociology that says that as society advances in modernity, religion retreats. Intellectual and scientific developments have undermined the spiritual, supernatural, superstitious and paranormal ideas on which religion relies for its legitimacy. Therefore, religion becomes more and more 'hollow', surviving for a while on empty until loss of active membership forces them into obscurity (Vexen Crabtree 2008). Modernity, on the contrary, is grounded in the everyday life experiences of the present. It includes but is not limited to the experience of space and time, of the self and others, of life's possibilities and perils - that is shared by men and women all over the world today. Modernity cuts across all boundaries of geography and ethnicity, of class and nationality, of religion and ideology (Berman 1988:15). Modernity homogenises cultures, destroys the boundaries that are essential to ethnic solidarity and a sense of identity, and creates new identities and rearranges the boundaries (Payne \& Nassar 2008:340). One of the features of modernity is the dichotomy between the public and private domain. In modern societies, institutions like the modern state, professions, bureaucracies (such as education and National Service), and the modern corporation have sprung up. These institutions define what is normative in terms of the mode of thought, conduct and social relationships (Chan Kok 2004:7).

When you visit many of the Christian universities in Ghana, it is very easy for one to see the impact of modernity on many young women and men. This effect is seen in their style of dress, hair and their entire way of life. Modernity has opened doors for students to boldly say what they think is their right, even if it goes against their faith.

\section{Increase in student population}

Another thing that is making it difficult for many Christian universities to maintain Christian virtues on their campuses is the increase in student population. In spite of the fact that it is the dream of every university to increase their student population and this would in effect increase their financial status to enable payment for their staff, improve infrastructure development and pay their bills, it however opens doors for people from various backgrounds to be enrolled as students. As students' enrolment increases, it comes with all sorts of dynamics that in effect have a negative impact on how Christian virtues and principles are maintained. The reason being that monitoring students' activities and their way of life on campus becomes more difficult, and therefore opens an avenue for all kinds of lifestyles. This usually happens at the blind side of the university's leadership and people who have the capacity to ensure discipline.

\section{The challenge of finding qualified Christians for various positions}

Finding qualified Christians for various key positions in Christian universities is often a huge problem, especially in Africa, and this will also affect the way Christian virtues and 
principles are maintained in some Christian universities. Although many Ghanaian Christian universities usually include in their advert for recruitment that 'the person must be a Christian', there is also a temptation to meet the NAB's requirements and, therefore, the Christian background of many of the staff is not well scrutinised. When this happens, this calibre of people will not have the moral confidence to talk about or ensure that Christian virtues are maintained by both students and staff.

\section{The way forward}

Philippians 4:8 admonishes us to think on '... whatsoever things are true, whatsoever things are honest, whatsoever things are just, whatsoever things are pure, whatsoever things are lovely, whatsoever things are of good report; ...' This suggests that by meditating on Christian virtues we will start practising them through the help of the Holy Spirit.

Based on our discussion on the realities and challenges of maintaining Christian virtues and ethos in Christian universities in Ghana, we therefore wish to suggest the following as some of the ways to address the challenges raised:

- Christian universities should focus on evangelism and discipleship by organising Christ-centred programmes that addresses the needs of contemporary students. The message may be the same but the style or approach must change.

- The background of staff chosen should be well investigated before they are finally employed. This will help institutional leadership to know the spiritual maturity of their prospective staff. It is wrong to assume that all staff are practising Christians.

- The institution should at least have monthly prayer and discipleship programmes in the form of bible studies and group discussion that will help people understand the scriptures and be established in faith.

- The leadership factor: Leadership is very important in the implementation of ideas and plans. According to Dessler (2012:34), it is the process of influencing the thoughts, emotions and behaviour of followers towards set goals. Christian universities should not appoint people into leadership positions just because of their credentials but also their commitment to ensuring that the university is achieving its purpose of being Christ-centred, mission minded and discipleship focused. Rieckkhoff, recommends that leaders of Christian Institutions should be faith leaders, guiding the faith development and faith life of all constituents. This, therefore, calls for the grooming and mentoring of young and committed Christians that are deemed to have what it takes to assume leadership positions both within and outside academia (2014:29). This approach would help Christian universities to have a reservoir of qualified Christians for various leadership positions.

\section{Conclusion}

This article made a case for maintaining Christian virtues and ethos in Christian universities in Ghana: The reality, challenges and the way forward. The research revealed that for a university to be called a Christian university it must adhere to core Christian beliefs and practices such as being Christcentred, mission minded and discipleship focused. This must also be reflected in the attitude of both students and staff in the way they relate to and manage God's resources.

Furthermore, with the exception of the MUC, the other two universities have properly organised programmes that integrate Christian principles into the academic lives of students. The study, however, cautioned that it is not enough to have such programmes in place but also the spiritual maturity of the facilitators should be considered. It was however noted that in addition to this programme, the universities used for the study do have regular weekly church services for the university community. In spite of this effort, attendance of both students and staff is usually between $50.0 \%$ and $70.0 \%$.

On the issue of how lecturers integrate Biblical principles into their lectures, about $40.0 \%$ of the respondents indicated that lecturers in most cases do integrate Biblical principles into their lectures, while $58.6 \%$ were of the view that lecturers do so in limited cases. Moreover, about $50.0 \%$ of the respondents revealed that lecturers do present themselves as Christians to a high extent.

The general assessment of modesty and opposite sex relationships on the campuses used for the study indicated to be progressively good and decent. The study unearthed the following as some of the major factors affecting the maintenance of Christian virtues and ethos in Christian universities in Ghana: Secularisation and modernity, increase in student population and the challenge of finding qualified Christians for various positions.

\section{Acknowledgements}

The authors would like to acknowledge the support that they had from the staff and students of various university colleges for their assistance and cooperation during the data collection stage of the research.

\section{Competing interests}

The authors declare that they have no financial or personal relationships which may have inappropriately influenced them in writing this article.

\section{Authors' contributions}

P.W. was responsible for the conceptual and theoretical aspect of the research and finalisation of the article. S.K.A. did the field work and data collection as well as prepare the first draft of the article.

\section{References}

Berman, M., 1988, All that is solid melt into air: The experience of modernity, Penguin Books Ltd., Middlesex, NJ.

Bosch, D.J., 1991, Transforming mission: Paradigm shifts in theology of mission, Orbis Books, Maryknoll, NJ. 
Chan Kok, W., 2004, The impact of modernity on spirituality, January edn., Global Missiology.

Chiroma, N., 2012, 'Critical evaluation of mentoring programs in theological seminaries of the Evangelical Church of West Africa (ECWA)', PhD dissertation, Stellenbosch University, Stellenbosch.

Chittenden, A., 2003, 'Perceptions of spirituality through an ethic of care: Comparative responses to spiritual dimensions of education (Part 1)', Religious Education Journal of Australia 19(1), 13-19.

Christian Service University College (CSUC), 2016a, History, viewed 03 April 2016, from http://www.csuc.edu.gh/csuc/p/about-csuc/our-university-college/our-history

Christian Service University College (CSUC), 2016b, Vision and mission statement, viewed 03 April 2016, from http://www.csuc.edu.gh/csuc/p/about-csuc/ouruniversity-college/our-mission-vision

Coffey, M., 2002, 'Let our children pray', Common Theology 1(1), 3-8.

Crabtree, V., 2008, Secularisation theory: Will modern society reject religion? What is Secularism?, viewed 06 April 2016, from http://www.humanreligions.info/ secularisation.html

Dessler, G., 2012, Supervision and leadership in a changing world, Pearson Education, Hudson, NJ.

Encyclopædia Britannica Online, 2016, Virtue, viewed 14 April 2016, from http:// www.britannica.com/topic/virtue-in-Christianity

English, L. \& Bowman, L., 2001, 'Working with experience: The mentor, the context, the possibility', British Journal of Theological Education 12(1), 37-52. https://doi. org/10.1558/jate.v12i1.37

Gilkerson, L., 2013, 6 Marks of Biblical modesty: How God brings sexy back, viewed 13 April 2016, from http://www.covenanteyes.com/2013/08/16/biblical-definition-ofmodesty/

Kim, K., 2009, Joining in with the spirit, Epworth Press, London.

Kretzschmar, L., 2006, 'The indispensability of spiritual formation for Christian leaders', Missionalia 34(2/3), 338-361.

Lindholm, J.A., Millora, M.L., Schwartz, L.M. \& Song-Spinosa, H., 2011, A Guidebook of promising practices: Facilitating college students' spiritual development, University of California, CA.

Lonsdale, D., 2005, 'The Church as context for Christian spirituality', in A., Holder (ed.), The Blackwell companion to Christian spirituality, p. 240, Blackwell Publishing Ltd, Oxford.
Methodist University College (MUC), 2016a, Faculty, viewed 03 April 2016, from http://www.mucg.edu.gh/academics/fac/index.html

Methodist University College (MUC), 2016b, History, viewed 03 April 2016, from http://www.mucg.edu.gh/aboutus/mucg-history.html

Methodist University College (MUC), 2016c, Vision and mission, viewed 03 April 2016, from http://www.mucg.edu.ghaboutus/mucg-mv.html

Newbigin, L., 1978, The open secret, William B. Eerdmans Publishing Company, Grand Rapids, MI.

Payne, R.J. \& Nassar, J.R., 2008, Politics and culture in the developing world: The impact of globalization, Pearson Education, New York.

Pentecost University College (PUC), 2010, Students handbook, viewed 03 April 2016, from http://www.pentvars.edu.gh/images/resources/studhandbook.pdf

Pentecost University College (PUC), 2016a, Mentorship, viewed 03 April 2016, from http://www.pentvars.edu.gh/index.php/life-on-campus/mentorship

Pentecost University College (PUC), 2016b, Vision and mission, viewed 03 April 2016, from http://newpucweb.ipower.com/about-us/vision-mission

Rieckkhoff, B.S., 2014, 'The development of faith leadership in novice principals', Journal of Catholic Education 17(2), 25-56.

Rock, A.D., 2006, 'Developing a spiritually-formative leadership mentoring ministry at Southwood Community Church', Doctor of Ministry dissertation, Liberty Baptist Theological Seminary, Lynchburg.

Tennent, C.T., 2010, Invitation to world mission: A Trinitarian missiology for the twenty-first century, Kregel Publications, Grand Rapids, MI.

Walls, A. \& Cathy Ross, C. (eds.), 2008, Mission in the 21st century: Exploring the five marks of global mission, Orbis Books, Maryknoll, NJ.

White, P., Okai, D. \& Asabea-Aboagye, M., 2015, 'Christ-centered mentorship: A case study of the faith and practice programme of Christian Service University College, Kumasi Ghana', All Nations University Journal of Applied Thought 4(3), 59-72.

World Council of Churches (WCC), 2013, 'Together towards life: Mission and evangelism in changing landscapes', in M. Lorke \& D. Werner (eds.), Ecumenical vision for 21st century, pp. 51-76, WCC Publications, Geneva.

Wright, C.J.H., 2006, The mission of God: Unlocking the bible's grand narrative, InterVarsity Press, Downers Grove, IL. 